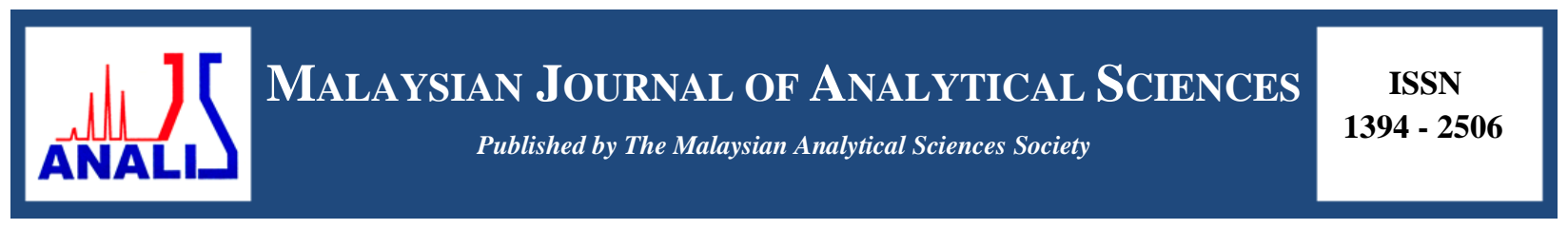

\title{
ISOLATION OF ACETYL ALEURITOLIC ACID FROM Pimeleodendron griffithianum (Euphorbiaceae)
}

\author{
(Pemisahan Asid Asetil Aleuritolik Daripada Pimeleodendron griffithianum (Euphorbiaceae)) \\ Rosmawati Abdul Aziz ${ }^{1,2} *$ and Norizan Ahmat ${ }^{1,2}$ \\ ${ }^{1}$ Faculty of Applied Sciences, \\ Universiti Teknologi MARA, 40450 Shah Alam, Selangor, Malaysia \\ ${ }^{2}$ Atta-ur-Rahman Institute for Natural Product Discovery, \\ Universiti Teknologi MARA, Puncak Alam Campus, 42300 Bandar Puncak Alam, Selangor, Malaysia. \\ *Corresponding author: rosmawatiaa@perlis.uitm.edu.my
}

Received: 24 February 2015; Accepted: 27 October 2015

\begin{abstract}
Pimeleodendron griffithianum, locally known as Perah ikan is available in Thailand, Peninsular Malaysia and Sumatra. The plant can be found in wet forest, secondary forest, pole forest, semi-swamps, and along logging roads or on hill slopes. In Malaysia, the stem of $P$. griffithianum being used as commercial timber. So far, no chemical constituents have been reported from $P$. griffithianum. In this study, a phytochemical study was conducted on the stem bark of $P$. griffithianum. The stem bark was obtained from Sungai Siput, Perak. The cleaned, chopped and dried stem-bark was extracted using acetone for several times. The separation of the components was carried out using vacuum liquid chromatography (VLC) followed by recrystallization method. The structure of the pure compound was elucidated by spectroscopic methods including nuclear magnetic resonance (NMR), ultraviolate - visible (UV-Vis) and comparison with literature. One compound (1) was isolated and identified as acetyl aleuritolic acid. This compound was reported for the first time from this plant.
\end{abstract}

Keywords: Pimeleodendron griffithianum, Euphorbiaceae, acetyl aleuritolic acid

\begin{abstract}
Abstrak
Pimeleodendron griffithianum, yang dikenali sebagai pokok Perah ikan oleh penduduk tempatan didapati di Thailand, Semenanjung Malaysia dan Sumatra. Pokok ini dapat ditemui di dalam hutan lembap, hutan sekunder, semi-paya dan di sepanjang jalan pembalakan atau di cerun bukit. Di Malaysia, batang pokok ini lazimnya digunakan sebagai kayu komersial. Setakat ini tidak ada laporan direkodkan mengenai bahan kimia yang ditemui daripada pokok ini. Dalam penyelidikan ini, satu kajian fitokimia telah dijalankan ke atas kulit batang P. griffhianum. Kulit batang pokok P.griffithianum diperolehi dari Sungai Siput, Perak. Kulit pokok yang telah dibersihkan, dipotong-potong kecil dan dikeringkan, diekstrak menggunakan aseton untuk beberapa kali. Pengasingan komponen dilakukan menggunakan kaedah kromatografi cecair vakum (VLC) diikuti dengan proses penghabluran semula. Struktur kimia sebatian tulen dijelaskan dengan kaedah spektroskopi termasuk spektroskopi resonans magnet nukleus (NMR), ultralembayung (UV) dan perbandingan dengan data literatur. Satu sebatian (1) yang dipisah dikenal pasti sebagai asid asetil aleuritolik. Sebatian ini dilaporkan buat kali pertama bagi tumbuhan ini.
\end{abstract}

Kata kunci: Pimeleodendron griffithianum, Euphorbiaceae, asid asetil aleuritolik

\section{Introduction}

Malaysia is known for its lush tropical rain forest. The natural resources of tropical rainforest in Malaysia bring many benefits to the country. Among them is supplying food resources to local community, timber, rattan and 
bamboo. Forests are not only a source of food supply and construction, but also a source of valuable medicinal plants. Forest plants in Malaysia contain many medicinal properties in the production of medicines. The tropical rain forests are chemically and biologically diverse resources as they synthesize various chemicals as defense agents against pests, diseases and predators. Euphorbiaceae is among the largest flowering plant families consisting of a wide variety of vegetative forms some of which are plants of great importance. The family is very diverse in range, comprises of all sorts of plants ranging from large woody trees through climbing habit to simple weed that grows prostrate to the ground. Euphorbiaceae is comprised of five subfamilies, 49 tribes, 317 genera and about 8000 species [1].

Pimeleodendron is a small genus in the Euphorbiaceae. Its distribution ranges from Peninsular Thailand to the Solomon Islands and tropical East Australia, Peninsular Thailand, Malay Peninsula, Sumatra, Borneo, Sulawesi, Lesser Sunda Islands, Moluccas, New Guinea, Solomon Islands, and NE Australia. Pimeleodendron comprises five species which are $P$. amboinicum, $P$. griffithianum, $P$. macrocarpum, $P$. zoanthogyne and $P$. dispersum [2]. Some species of this genus are economically important since they provide food, medicine, or varnish for local people. The wood of $P$. macrocarpum is used in house construction. In Sumatra, the fruit of $P$. griffithianum is used for seasoning. In eastern Malay Peninsula $P$. amboinicum furnishes edible seeds, which taste like hazelnuts; its bark being used as a purgative; the juice of the leaves, used in a mixture, cleans the mouths of children, and acts as a gentle purgative (adults can eat the leaves without purging) while the latex serves as a varnish. People in the Solomon Islands drink an infusion of the bark of $P$. amboinicum as a remedy for fever [2].

Pimeleodendron griffithianum (P. griffithianum) is one of the species in the genus pimeleodendron. This plant is locally known as Perah ikan. It is a mid-canopy tree up to $30 \mathrm{~m}$ tall. The bark is light brown, rugose, glabrous, and the inner bark is light brown about $2 \mathrm{~mm}$ thick with pale yellow sap. It is distributed in Thailand, Peninsular Malaysia, Sumatra, Borneo and Philippines. The plant usually found in wet forest, secondary forest, and pole forest, semi-swamps, and along logging roads or on hill slopes [2]. In Malaysia, P. griffithianum is found in over hill dipterocarp forest. The plant was used mainly as commercial timber. The timber being used for general light or temporary construction, interior trim, lining, shelving, joinery, furniture, mouldings, tool handle for non-impact purposes and plywood [3]. It also be used as edible fruit [4] while in Sumatra, the fruit of P. griffithianum is used for seasoning [2]. There is very limited information available regarding the uses of $P$. griffithianum. Currently, there is no chemical constituents have been reported from P. griffithianum.

\section{Instrumentation}

\section{Materials and Methods}

The NMR spectra were recorded on a Bruker AV300 NMR spectrometer 1D-NMR $\left({ }^{1} \mathrm{H}-\mathrm{NMR},{ }^{13} \mathrm{C}-\mathrm{APT}\right)$ and 2DNMR (HMQC, HMBC and COSY) with TMS as internal standard and $\mathrm{CDCI}_{3}$ as solvent. UV spectra were determined using UV-Vis spectrophotometer LAMBDA 35 Perkin Elmer. Silica gel 60 G (Merck 7747) was used for vacuum liquid chromatography. TLC were performed on pre-coated silica gel $60 \mathrm{~F}_{254}$ plates (Merck 5554) and visualized under UV light and by spraying with Cerium sulphate reagent followed by heating.

\section{Plant collection}

Fresh stem bark was collected from Sungai Siput, Perak. The stem bark was cleaned, chopped and dried under shade at room temperature until completely dry $(5.60 \mathrm{~kg})$. Then, it was ground to coarse powder using mechanical grinder $(5.05 \mathrm{~kg})$.

\section{Extraction and isolation}

The extract of the $P$. griffithianum was obtained by taking $4 \mathrm{~kg}$ of the powder, macerated with 5 liter of acetone in a container covered with aluminum foil and left to macerate overnight. The solvent was then filtered and evaporated under reduced pressure to obtain crude extract (207.6 g) [5]. The crude extract was then dissolved in $200 \mathrm{ml}$ methanol and added with $2 \mathrm{~L}$ diethyl ether to precipitate tannin constituents. Decantation and evaporation of $\mathrm{MeOH}$-dietyl ether soluble fraction gave crude extract that contain less tannin [6]. Crude extract obtained from this process $(187.6 \mathrm{~g})$ was used for further isolation and purification. 
The extract which contain less tannin was fractionated by vacuum liquid chromatography (VLC) eluted with hexane: chloroform: ethyl acetate from 10:0:0 to 8:0:2. The fractionation produced 16 fractions. Fraction 10 was observed as green crystal with the mass of $138.0 \mathrm{mg}$. This fraction was washed several times with hexane. From the recrystallization processes, compound (1) was obtained as white needles $(10.1 \mathrm{mg})$. The compound was detected by TLC profile and confirmed by $\mathrm{CeSO}_{4}$ reagent. The compound (1) was characterized using NMR, UV-Vis and comparison with previous data.

\section{Results and Discussion}

Compound (1): Crystallized as white needles; showed maximum absorption of $\lambda\left(\mathrm{CHCI}_{3}\right) 242.22 \mathrm{~nm}$. It indicated that the compound did not contain chromophore. ${ }^{13} \mathrm{C}$ APT NMR spectrum $\left(\mathrm{CDCI}_{3}\right)$ of compound (1) displayed 32 carbon resonances; they are nine quartenary carbons $(\mathrm{C})$ at $\delta_{\mathrm{C}} 29.3(\mathrm{C}-20), 37.3(\mathrm{C}-13), 37.6(\mathrm{C}-4), 37.9(\mathrm{C}-10)$, 39.0 (C-8), 51.5 (C-17), 160.5 (C-14), 184.2 (C-28) and 171.0 (C-1'), five methine groups $(\mathrm{CH})$ at $\delta_{\mathrm{C}} 41.9(\mathrm{C}-18)$, $49.2(\mathrm{C}-9), 55.3(\mathrm{C}-5), 81.0(\mathrm{C}-3), 117.0(\mathrm{C}-15)$, ten methylene groups $\left(\mathrm{CH}_{2}\right)$ at $\delta_{\mathrm{C}} 17.3(\mathrm{C}-11), 18.7(\mathrm{C}-6), 23.4(\mathrm{C}-$ 2), $30.7(\mathrm{C}-22), 31.3(\mathrm{C}-16), 33.6(\mathrm{C}-21), 35.6(\mathrm{C}-8), 37.3(\mathrm{C}-1)$, and $40.7(\mathrm{C}-7)$ and eight methyl group $\left(\mathrm{CH}_{3}\right)$ at $\delta_{\mathrm{C}}$ 16.6 (C-25), 16.6 (C-24), 21.3 (C-2'), 22.5 (C-27), 26.2 (C-26), 27.9 (C-23), 28.6 (C-3) and 31.8 (C-29). ${ }^{1} \mathrm{H}$ NMR $\left(300 \mathrm{MHz}, \mathrm{CDCI}_{3}\right) \delta_{\mathrm{H}}: 0.84(\mathrm{H}-23, \mathrm{~s}, 3 \mathrm{H}), 0.87(\mathrm{H}-24 \mathrm{~s}, 3 \mathrm{H}), 0.90(\mathrm{H}-27, \mathrm{H}-30, \mathrm{~s}, 3 \mathrm{H}), 0.92(\mathrm{H}-29, \mathrm{~s}, 3 \mathrm{H}), 0.94(\mathrm{H}-$ 25, H-26 ,s, 3H), $2.03(\mathrm{H}-2$ ', s, 3H), $4.45(\mathrm{H}-3, \mathrm{dd}, J=6.54,9.18 \mathrm{~Hz}, 1 \mathrm{H}), 5.50(\mathrm{H}-15, \mathrm{dd}, J=3.19,7.77 \mathrm{~Hz}, 1 \mathrm{H})$. The ${ }^{1} \mathrm{H}$ and ${ }^{13} \mathrm{C}$ NMR assignments are given in Table 1.

The presence of thirty-two resonances showed a pentacyclic triterpene skeleton. The signals at $\delta_{\mathrm{C}} 184.25$ and 171.02 indicate the presence of carboxylic acid and acetoxy carbonyl function. Position of acetoxy group was determined from HMQC spectrum, which revealed that protons were found to be related with C-3 and it can be recognized from HMBC spectrum of quaternary carbon at acetoxy group. Position of carboxylic acid group was determined from HMBC spectrum, which revealed that carbon on carbonyl groups and $\mathrm{C}-17$ were found correlate to protons at $\mathrm{C}-16$ and $\mathrm{C}-22$. The double bond $(\mathrm{C}=\mathrm{C})$ showed deshielding condition at $\delta_{\mathrm{C}} 160.5$ and 116.8 , which is a typical C14-C15 double bond of taraxerane skeleton. Position of this double bond was clearly determined from the HMBC spectrum, which revealed that $\mathrm{H}-15$ correlate to $\mathrm{C}-15$ and recognized with carbon $\mathrm{C}-14 .{ }^{1} \mathrm{H}$ NMR spectrum showed a characteristic singlet at $\delta_{\mathrm{H}} 2.03$ assigned to acetoxy protons, a doublet doublet proton at $5.50(\mathrm{~J}=7.77$ and $3.19 \mathrm{~Hz}$ ) indicating a proton on the trisubstituted double bond adjacent to methylene function. Another doublet of doublet proton resonated at $\delta_{\mathrm{H}} 4.45(J=9.18$ and $6.54 \mathrm{~Hz})$ assigned to the ubiquitous $3 \alpha$ methane proton germinate to the acetoxy function of triterpene skeleton. Seven tertiary methyls appeared as singlets in the region $\delta_{\mathrm{H}} 0.84-$ 0.94. The above data of ${ }^{1} \mathrm{H}$ NMR and ${ }^{13} \mathrm{C}$ APT NMR for the compound (1) was identical with the reported data of that acetyl aleuritolic acid [7 - 10]. The structure of acetyl aleuritolic acid is shown in Figure 1.

Table 1. ${ }^{1} \mathrm{H}$ and ${ }^{13} \mathrm{C}$ NMR assignments of compound (1)

\begin{tabular}{lcll}
\hline Position of $\mathbf{C}$ & $\boldsymbol{\delta}_{\mathbf{C}}$ & $\boldsymbol{\delta}_{\mathbf{H}}$ & $\mathbf{A P T}$ \\
\hline $\mathbf{1}$ & 37.3 & $1.04,1.62$ & $\mathrm{CH}_{2}$ \\
$\mathbf{2}$ & 23.4 & $1.61,1.65$ & $\mathrm{CH}_{2}$ \\
$\mathbf{3}$ & 80.9 & $4.45(1 \mathrm{H}, \mathrm{dd}, \mathrm{J}=6.54,9.18 \mathrm{~Hz})$ & $\mathrm{CH}$ \\
$\mathbf{4}$ & 37.7 & - & $\mathrm{C}$ \\
$\mathbf{5}$ & 55.5 & 0.88 & $\mathrm{CH}$ \\
$\mathbf{6}$ & 18.7 & $1.48,1.58$ & $\mathrm{CH}_{2}$ \\
$\mathbf{7}$ & 40.7 & $1.27,1.99$ & $\mathrm{CH}_{2}$ \\
$\mathbf{8}$ & 39.0 & - & $\mathrm{C}$ \\
$\mathbf{9}$ & 49.0 & 1.44 & $\mathrm{CH}$ \\
$\mathbf{1 0}$ & 37.9 & - & $\mathrm{C}$ \\
$\mathbf{1 1}$ & 17.3 & $1.44,1.62$ & $\mathrm{CH}_{2}$ \\
\hline
\end{tabular}


Rosmawati \& Norizan: ISOLATION OF ACETYL ALEURITOLIC ACID FROM Pimeleodendron griffithianum (Euphorbiaceae)

Table 1 (cont'd). ${ }^{1} \mathrm{H}$ and ${ }^{13} \mathrm{C}$ NMR assignments of compound (1)

\begin{tabular}{lcll}
\hline Position of C & $\boldsymbol{\delta}_{\mathbf{C}}$ & $\boldsymbol{\delta}_{\mathbf{H}}$ & $\mathbf{A P T}$ \\
\hline $\mathbf{1 2}$ & 33.3 & $1.60,1.80$ & $\mathrm{CH}_{2}$ \\
$\mathbf{1 3}$ & 37.3 & - & $\mathrm{C}$ \\
$\mathbf{1 4}$ & 160.5 & - & $\mathrm{C}$ \\
$\mathbf{1 5}$ & 116.8 & $5.5(1 \mathrm{H}, \mathrm{dd}, \mathrm{J}=3.19,7.77 \mathrm{~Hz})$ & $\mathrm{CH}$ \\
$\mathbf{1 6}$ & 31.3 & $1.91,2.36$ & $\mathrm{CH}_{2}$ \\
$\mathbf{1 7}$ & 51.5 & - & $\mathrm{C}$ \\
$\mathbf{1 8}$ & 41.3 & $2.26(1 \mathrm{H}, \mathrm{dd}, \mathrm{J}=13.70,2.70 \mathrm{~Hz})$ & $\mathrm{CH}$ \\
$\mathbf{1 9}$ & 35.3 & $1.06,1.23$ & $\mathrm{CH}_{2}$ \\
$\mathbf{2 0}$ & 29.3 & - & $\mathrm{C}$ \\
$\mathbf{2 1}$ & 33.6 & $1.05,1.15$ & $\mathrm{CH}_{2}$ \\
$\mathbf{2 2}$ & 30.7 & $1.44,1.72$ & $\mathrm{CH}_{2}$ \\
$\mathbf{2 3}$ & 27.9 & $0.84(3 \mathrm{H}, \mathrm{s})$ & $\mathrm{CH}_{3}$ \\
$\mathbf{2 4}$ & 16.6 & $0.87(3 \mathrm{H}, \mathrm{s})$ & $\mathrm{CH}_{3}$ \\
$\mathbf{2 5}$ & 15.6 & $0.94(3 \mathrm{H}, \mathrm{s})$ & $\mathrm{CH}_{3}$ \\
$\mathbf{2 6}$ & 26.2 & $0.94(3 \mathrm{H}, \mathrm{s})$ & $\mathrm{CH}_{3}$ \\
$\mathbf{2 7}$ & 22.5 & $0.90(3 \mathrm{H}, \mathrm{s})$ & $\mathrm{CH}_{3}$ \\
$\mathbf{2 8}$ & 184.3 & - & $\mathrm{C}$ \\
$\mathbf{2 9}$ & 31.8 & $0.92(3 \mathrm{H}, \mathrm{s})$ & $\mathrm{CH}_{3}$ \\
$\mathbf{3 0}$ & 28.6 & $0.90(3 \mathrm{H}, \mathrm{s})$ & $\mathrm{CH}_{3}$ \\
$\mathbf{1}$ & 171.0 & - & $\mathrm{C}$ \\
$\mathbf{2}$ & 21.3 & $2.03(3 \mathrm{H}, \mathrm{s})$ & $\mathrm{CH}_{3}$ \\
\hline
\end{tabular}

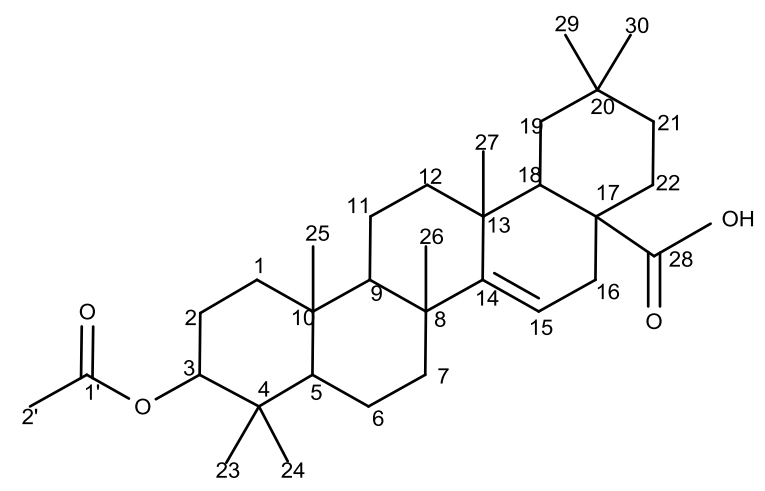

Figure 1. The chemical structure of acetyl aleuritolic acid 


\section{Conclusion}

Acetyl aleuritolic acid was successfully isolated from the stem bark of $P$. griffithianum. This compound is reported for the first time from this plant. The structure of the pure compound was elucidated by spectroscopic methods including nuclear magnetic resonance (NMR), ultraviolate - visible (UV-Vis) and comparison with literature.

\section{Acknowledgement}

We thank to the Faculty of Applied Sciences, Universiti Teknologi MARA, Shah Alam for providing the laboratory facilities to carry out this research. The authors also would like to thanks to Mrs. Zuriati, and Miss Faeza from Sekolah Kebangsaan Pos Piah, and Mr. Azman, one of the local resident in Sungai Siput, Perak for his assistance during the stem bark collection of P. griffithianum.

\section{References}

1. Mwine, J. T. and Van Damme, P. (2011). Why do Euphorbiaeceae tick as medicinal plants? A review of Euphorbiaceae family and its medicinal features. Journal of Medicinal Plants Research, 5(5): 652 - 662.

2. Djarwaningsih, T. (2004). Revision of Pimeleodendron (Euphorbiaceae) in Malesia. Blumea - Biodiversity, Evolution and Biogeography. Plants, 49(2): 407 - 423.

3. MTC Wood Wizard, Perah ikan. (2012). Online access from www.mtc.com.my.

4. Eswani, N., Abd, K., Nazre, M., Noor, A. G. A., and Ali, M. (2010). Medicinal plant diversity and vegetation analysis of logged over Hill Forest of Tekai Tembeling Forest Reserve, Jerantut, Pahang. Journal of Agricultural Science, 2(3): 189 - 210.

5. Jones, W. P. and Kinghorn, A. D. (2005). Extraction of plant secondary metabolites. Natural Products Isolation, Method in Biotechnology 20: 323 - 351.

6. Wibowo, A., Ahmat, N., Hamzah, A. S., Ismail, N. H., Ahmad, R., and Jaafar, F. M. (2012). Resveratrol oligomers from the stem bark of Dryobalanops aromatica. Biochemical Systematics and Ecology, 40: 62 - 64.

7. McLean, S., Perpick-Dummont, M., Reynolds, W. F., Jacobs, H. and Lachmansing, S. S. (1987). Unambiguous structural and nuclear magnetic resonance spectral characterization of two triterpenoids of Maprounea guianensis by two-dimensional nuclear magnetic resonance spectroscopy. Canadian Journal of Chemistry, 6(7): $2519-2525$.

8. Prabowo, W. C., Wirasutisna, K. R. and Insanu, M. (2013). Isolation and characterization of 3-acetyl aleuritolic acid and scopoletin from stem bark of Aleurites Moluccana (L.) willd. International Journal of Pharmaceutical Science, 5(3): 851 - 853.

9. Agidew, E., Reneela, P. and Deyou, T. (2013). Phytochemical investigation of Sapium ellipticum. Journal of Natural Product Plant Resource, 3(5): 1 - 6.

10. Viswanadh, G. S., Ramaiah, P. A., Laatsch, H. and Maskey, R. (2006). Chemical constituents of the heartwood and barks of Homonoia riparia. Journal of Tropical Medicinal Plants, 7(2): 267 - 273. 